\title{
Preliminary study of the molluscicidal and larvicidal properties of some essential oils and phytochemicals from medicinal plants
}

\author{
Aristides M. Leite, ${ }^{1}$ Edeltrudes de O. Lima, ${ }^{2}$ Evandro L. de Souza, ${ }^{*}, 3$ Margareth de F. F. M. \\ Diniz, ${ }^{1}$ Sônia Pereira Leite, ${ }^{4}$ Aline L. Xavier, ${ }^{1}$ Isac A. de Medeiros ${ }^{1}$ \\ ${ }^{1}$ Laboratório de Tecnologia Farmacêutica, Universidade Federal da Paraíba, 58059-900 \\ João Pessoa-PB, Brasil \\ ${ }^{2}$ Laboratório de Micologia, Departamento de Ciências Farmacêuticas, Universidade Federal da Paraíba, \\ 58059-900 João Pessoa-PB, Brasil \\ ${ }^{3}$ Departamento de Nutrição, Universidade Federal da Paraíba, 58059-900 João Pessoa-PB, Brasil \\ ${ }^{4}$ Departamento de Embriologia e Histologia, Universidade Federal de Pernambuco, \\ 50670-420 Recife-PE, Brasil
}

\begin{abstract}
RESUMO: "Estudo preliminar das propriedades moluscicidas e larvicidas de alguns óleos essenciais e fitoconstituintes de plantas medicinais". Este estudo teve como objetivo avaliar a atividade moluscicida e larvicida de alguns óleos essenciais e fitoconstituintes de plantas medicinais. A atividade moluscicida e larvicida foi determinada empregando-se, respectivamente, o teste de letalidade contra náupilos de Artemia salina Leach. Artemiidae e contra larvas de Aedes aegypti L. Culicidae. Os óleos essenciais de Eugenia uniflora L. Myrtaceae, Laurus nobilis L. Lauraceae, Origanum vulgare L. Lamiaceae e os fitoconstituintes $\alpha$-pineno e eugenol mostraram bioatividade citotóxica frente $A$. salina com valores de $\mathrm{CL}_{50}$ entre 9,59 e $253,43 \mu \mathrm{L} / \mathrm{mL}$. Os óleos essenciais de E. uniflora, $M$. piperita, $O$. vulgare e $R$. officinalis apresentaram atividade de embriotoxicidade sobre as larvas de A. aegypti mostrando uma variação de inibição de viabilidade entre 40 e $100 \%$. Estes resultados demonstram o potencial de bioatividade desses óleos essenciais e fitoconstituintes e justificam, parcialmente, o desenvolvimento de estudos com esses produtos para uso popular.
\end{abstract}

Unitermos: Óleos essenciais, fitoconstituintes, Artemia salina, Aedes aegypti, toxicidade.

\begin{abstract}
This study aimed to evaluate the molluscicidal and larvicidal activity of some essential oils and phytochemicals from medicinal plants. Molluscicide and larvicidal activity were determined by, respectively, the lethality bioassays using Artemia salina Leach. Artemiidae and Aedes aegypti L. Culicidae larvae. Essential oils from Eugenia uniflora L. Myrtaceae, Laurus nobilis L. Lauraceae, Origanum vulgare L. Lamiaceae and the phytochemicals $\alpha$-pinene and eugenol presented citotoxicity toward Artemia salina with $\mathrm{CL}_{50}$ values between 9.59 and $253.43 \mu \mathrm{L} / \mathrm{mL}$. Essential oils from E. uniflora, M. piperita, O. vulgare and $R$. officinalis showed embryotoxicity on Aedes aegypti larvae with a viability inhibition between 40 and $100 \%$. These results show the bioactivity of the assayed essential oils and phytochemicals and, partially, justify their insertion in further evaluation in order to establish a safe exploitation of their biological potentiality.
\end{abstract}

Keywords: Essential oils, phytochemicals, Artemia salina, Aedes aegypti, toxicity.

\section{INTRODUCTION}

The toxic potential of a plant product is known as one of the main parameters to be scientifically evaluated when regarded the use of its bioactivity in classical or alternative therapies (Ruiz et al., 2005). The larvae of Artemia salina Leach., Artemiidae, has been used as target organism in assays focusing the detection of bioactivity of plants and derivatives, particularly their toxicity (Alves et al., 2000). Brine shrimp lethality assay is known as an efficient, safe, fast and reproducible procedure to assess biological potentiality of new compounds (Meyer et al., 1982) and requires a small amount of the assayed substance (2-20 mg) (Svensson et al., 2005). Still, it has presented satisfactory correlation with insecticidal, antiTrypanosoma cruzi (Alves et al., 2000; Montanher et al., 2002) and citotoxicity property to some solid human tumors (McLaughlin et al., 1998).

Brine shrimp lethality assay has been applied in preliminary studies of toxicity with algae, plant products, dentistry materials, to screen mould toxins and exposure to heavy metals e pesticides (Ara et al., 1999; Martinez et 
al., 1999; Pelka et al., 2000; Lima et al., 2002; Ruiz et al., 2005; Lhullier et al., 2006).

A. salina Leach. is a microcrustaceous inserted in the Arthropoda division, Crustaceae class, Branchiopoda subfamily and Anostraca order. It has an 8 to $10 \mathrm{~mm}$ length, with coloring (light red, pink or golden brown) ranging according to its habitat (Lopes et al., 2002). The one reproduces quickly and its dried eggs can be stored for approximately ten years keeping viability to emerge when exposed to saline water (Parra et al., 2001; Montanher et al., 2002).

The dengue presents as an endemic disease in Africa, Asia, Central and South America and, in Brazil, the disease is widespread meaning a steady worrying for the public health system (Funasa, 2002; Luna et al., 2005). The discovery of new substances with potential application to control the survival and reproduction of their vector, that is Aedes aegypti L. Culicidae, is primordial when regarded the role that the vector plays in the disease spreading. Still, it is well established that the control of the vector survival and reproduction is the unique viable approach to avoid the dengue high prevalence (Marcondes, 2001).

Insecticides currently used to control the $A$. aegypti proliferation need a continuous application with progressively increased dosages which possibly means risk of toxicity for humans and animals. Some studies has been carried out with the purpose of discovering alternative products, including plant derivatives, with insecticidal properties to be applied for inhibiting the survival of $A$. aegypti (Luna et al., 2005).
Regarding the lack of similar studies, this research had as purpose to verify the toxicity property, particularly the molluscicide and larvicidal property, of some essential oils and phytochemicals from medicinal plants using bioassays with $A$. salina and $A$. aegypt.

\section{MATERIAL AND METHODS}

\section{Essential oils and phytochemicals}

Essential oils from Laurus nobilis L. Lauraceae and Origanum vulgare L. Lamiaceae were obtained from Ferquimica Ind. Com. Ltda. (Vargem Grande Paulista-SP, Brazil) and their quality parameters (appearance, color, purity, odor, density $20^{\circ} \mathrm{C}$, refraction index $20^{\circ} \mathrm{C}$ ) were described in an accompanying technical report. This provider produces essential oils by steam distillation on industrial scale. The essential oils from Eugenia uniflora L. Myrtaceae, Mentha piperita L. Lamiaceae and Rosmarinus officinalis L. Lamiaceae were supplied by the Laboratory of Pharmaceutical Technology, Federal University of Paraíba, João Pessoa-PB, Brazil, and they were obtained by steam distillation according to Matos (1988). All essential oils were chosen to be included in the toxicity assays based on their biological potential according to specialized literature and use in popular medicine (Table 1).

The phytochemicals $\alpha$-pinene (monoterpene) and eugenol (phenolic) were supplied by the Laboratory of Pharmacotechnique, State University of Ponta Grossa, Ponta Grossa-PR, Brazil.

Table 1. Plants from which were obtained the essential oils used in the toxicity assays and their use in the folk medicine.

\begin{tabular}{|c|c|c|c|c|}
\hline $\begin{array}{c}\text { Plant } \\
\text { (popular name) }\end{array}$ & Family & Part of the plant* & Use in folk medicine & References \\
\hline $\begin{array}{l}\text { Laurus nobilis L. } \\
\text { (Laurus) }\end{array}$ & Lauraceae & Leaves & $\begin{array}{l}\text { Analgesic, anti-acid, anti-spasmodic, anti- } \\
\text { rheumatic, anti-dispeptic, expectorant }\end{array}$ & $\begin{array}{l}\text { Oliveira et al., } 2006 \\
\text { Conforti et al., } 2006\end{array}$ \\
\hline $\begin{array}{l}\text { Origanum vulgare } \\
\text { L. (Orégano) }\end{array}$ & Lamiaceae & Leaves & $\begin{array}{l}\text { Analgesic, anti-rheumatic, anti-septic, } \\
\text { expectorant, parasiticide, laxative. }\end{array}$ & $\begin{array}{c}\text { Sellar, } 2002 \\
\text { Souza et al., } 2007\end{array}$ \\
\hline $\begin{array}{l}\text { Mentha piperita } \mathrm{L} . \\
\text { (Mint) }\end{array}$ & Lamiaceae & Leaves & $\begin{array}{l}\text { Anti-spamodic, stimulanting, sinusitis, anti- } \\
\text { piretic, diuretic, cough, asthma, analgesic, } \\
\text { halitose, anti-emetic, parasiticide }\end{array}$ & $\begin{array}{l}\text { Matos, } 1998 \\
\text { Vidal et al., } 2007\end{array}$ \\
\hline $\begin{array}{l}\text { Rosmarinus } \\
\text { officinalis L. } \\
\text { (Rosemary) }\end{array}$ & Lamiaceae & Leaves & $\begin{array}{l}\text { Anti-rheumatic, stimulating, dispeptic, } \\
\text { antioxidant }\end{array}$ & $\begin{array}{l}\text { Sant'Ana \& Mancini- } \\
\text { Filho, } 1999\end{array}$ \\
\hline $\begin{array}{l}\text { Eugenia uniflora L. } \\
\text { (brazilian cherry) }\end{array}$ & Myrtaceae & $\begin{array}{l}\text { Leaves and } \\
\text { rosebuds }\end{array}$ & $\begin{array}{l}\text { Odontalgia, dispeptic, onichomycosis, } \\
\text { endoparasitosis, respiratory infections, } \\
\text { stimulating, repellent insecticidal, halitosis }\end{array}$ & Dip et al., 2004 \\
\hline
\end{tabular}

*Part of the plant used in the essential oil extraction

\section{Bioassays with Artemia salina $\mathbf{L}$.}

In this assay was assessed the molluscicidal activity of the essential oils from E. uniflora L., L. nobilis L. e $O$. vulgare L. and phytochemicals alfa-pinene, betapinene and eugenol. For this, cysts of $A$. salina were added to flask containing sterile saline water $\left(\mathrm{pH} 8.5,29^{\circ} \mathrm{C}\right)$ and left under artificial lighting for $24 \mathrm{~h}$ in order to obtain the larvae used in the assay. After that, thirteen to fifteen larvae were exposed (in sterile assay tubes) to $5 \mathrm{~mL}$ of the solutions, prepared in Tween 80 , DMSO and sterile saline water, with different concentrations $(10-1000 \mu \mathrm{g} / \mathrm{mL})$ of the essential oils and phytochemicals. The suspensions were incubated for $24 \mathrm{~h}$ under artificial lighting. At the end 
of the incubation period, the count of the number of alive and killed larvae was carried out. $A$. salina larvae cultured in Tween 80, DMSO and sterile saline water without adding essential oil or phytochemical were used as control experiments. Each assay was performed in triplicate.

The results were expressed as $\mathrm{LC}_{50}$ value (concentration able to kill $50 \%$ or more of the larvae). $\mathrm{LC}_{50}$ was found by linear regression (square equation) using a significance level of $5 \%(\mathrm{p}<0.05)$ and reliability index of $95 \%$. For this the Probitos Statistical Methods/Microcal Origin 6.0 software was used. When found value of $\mathrm{LC}_{50}$ $<1000 \mu \mathrm{g} / \mathrm{mL}$ the assayed product was regarded as toxic bioactive compound; on the other hand, when found value of $\mathrm{LC}_{50} \geq 1000 \mu \mathrm{g} / \mathrm{mL}$ the assayed compound was regarded as non-toxic (Meyer et al., 1982; McLaughlin et al., 1998; Parra et al., 2001; Lopes et al., 2002).

\section{Bioassay with $A$. aegypti}

In this assay was assessed the embryotoxicity activity of the essential oils from $C$. aromaticus L., $M$. piperita L., $O$. vulgare L. and $R$. officinalis L. Larvae of $A$. aegypti used in this assay were supplied by the Environmental Surveillance Center, Recife city hall, RecifePE, Brazil. The development and maintenance of the larvae (L1, L2 and L3 biological phases), pulps and adults insects were carried out according to procedure described by Silva et al. (1998). In the assay, ten larvae in the L1 phase were cultured in solutions with different concentration of the essential oils (0.8-0.2 $\mu \mathrm{g} / \mathrm{mL})$ prepared in DMSO using a photophase of $12 \mathrm{~h}$. The larvae development was observed in intervals of $24 \mathrm{~h}$ of exposure using inverted microscope (LEICA). A. aegypti larvae cultured in DMSO and sterile distilled water without adding essential oil were used as control experiments. Each assay was performed in triplicate and the results were expressed as percent number of nonviable larvae (viability inhibition) in comparison with the number of viable larvae found in the control assay.

\section{RESULTS}

The results of the molluscicidal assays of some essential oils and phytochemicals on Artemia salina Leach. Artemiidae are shown in Table 2. The essential oils from Eugenia uniflora L. Myrtaceae, Laurus nobilis L. Lauraceae and Origanum vulgare L. Lamiaceae, and the phytochemicals $\alpha$-pinene and eugenol presented toxicity toward A. salina being found a $\mathrm{LC}_{50}$ value lower than 1000 $\mu \mathrm{g} / \mathrm{mL}$ for all of them. Essential oils from E. uniflora, $L$. nobilis and $O$. vulgare showed $\mathrm{LC}_{50}$ of 253.4, 89.88 and $14.91 \mu \mathrm{g} / \mathrm{mL}$, respectively. $\mathrm{LC}_{50}$ of 9.59 and $47.16 \mu \mathrm{g} /$ $\mathrm{mL}$ were found, respectively, to $\alpha$-pinene and eugenol. As can be seen, there was heterogeneity among the values of $\mathrm{LC}_{50}$ found for the assayed products. $\alpha$-Pinene, showed the smallest $\mathrm{LC}_{50}$ value.

The results of the larvicidal activity of some essential oils from medicinal plants on larvae of A. aegypti are shown in Table 3. The essential oil from E. uniflora and $O$. vulgare showed a $100 \%$ inhibition of the A. aegypti larvae viability in all assayed concentrations. The mortality toke place in a short time ( $2 \mathrm{~h}$, data not shown) becoming impossible the observation of the larvae development in later times The fast and high mortality rate was probably established due to the interference of the assayed essential oils on the synthesis and/or chitin reabsorption in the larvae (Silva et al., 1998).

It was observed an inhibition of the larvae development between 24 to $72 \mathrm{~h}$ in the assays with Rosmarinus officinalis L. Lamiaceae and Mentha piperita L. Lamiaceae essential oil. In this assays the larvae were kept in L1 phase form (data not shown). R. officinalis essential oil when assayed at concentration of $0.2 \mu \mathrm{g} / \mathrm{mL}$ presented an $80 \%$ inhibition of the larvae viability, while M. piperita essential oil at the same concentration provided a $40 \%$ inhibition. These oils at concentration of 0.4 and 0.8 $\mu \mathrm{g} / \mathrm{mL}$ caused a $100 \%$ inhibition of the larvae viability. Control assays using DMSO showed development of the larvae up to L2 form in $24 \mathrm{~h}$ and it was noted that $60 \%$ of the assayed larvae presented in development viable form.

Table 2. Molluscicidal activity of some essential oils and phytochemicals from medicinal plants on A. salina L. (results expressed as average value of $\mathrm{LC}_{50}$ ).

\begin{tabular}{lc}
\hline Natural products & $\mathrm{LC}_{50}(\mu \mathrm{g} / \mathrm{mL})$ \\
\hline E. uniflora $\mathrm{EO}$ & 253.43 \\
L. nobilis EO & 89.88 \\
O. vulgare EO & 14.91 \\
$\alpha$-Pinene & 9.59 \\
Eugenol & 47.16 \\
\hline
\end{tabular}

EO: essential oil

Table 3. Larvicidal activity of some essential oils from medicinal plants on $A$. aegypti larvae. Results expressed as percent inhibition of the viable larvae.

\begin{tabular}{lccccc}
\hline \multirow{2}{*}{ Essential oils } & \multicolumn{3}{c}{$\begin{array}{c}\text { Concentrations } \\
\text { (in } \mu \mathrm{g} / \mathrm{mL})\end{array}$} & \multicolumn{2}{c}{ Control * } \\
\cline { 2 - 6 } & 0.2 & 0.4 & 0.8 & DMSO & water \\
\hline Eugenia uniflora & 100 & 100 & 100 & 40 & 40 \\
M. piperita & 40 & 70 & 100 & 40 & 40 \\
O. vulgare & 100 & 100 & 100 & 40 & 40 \\
R. officinalis & 80 & 100 & 100 & 40 & 40 \\
\hline
\end{tabular}

*Percent of unviable cells in comparison to the total of larvae found in the control assays

\section{DISCUSSION}

Terpenic compounds, mainly monoterpenes, are found in the most essential oils (Simões \& Spitzer, 2003). $\alpha$-Pinene and $\beta$-pinene (monoterpenes) are found in Origanum vulgare L. Lamiaceae essential oil, while eugenol (phenolic) is found in Rosmarinus officinalis 
L. Lamiaceae essential oil (Tognolini et al., 2006). Triterpenes isolated from Euphorbia L. species showed no toxicity on $A$. salina, while strong toxicity was noted in diterpenes (Santos et al., 2007). Meyer et al. (1982) noted toxicological property of thymol, phenolic found in $O$. vulgare essential oil, with $\mathrm{LC}$ of $514 \mu \mathrm{g} / \mathrm{mL}$ against $A$. salina.

Extract from Eugenia uniflora L. Myrtaceae leaves presented no bioactivity against Biomphalaria glabrata and A. salina (Alves et al., 2000) and these findings were in agreement with those found for Montanher et al. (2002). On the other hand, Baccharis trimera (Less.) DC. Asteraceae showed strong toxicity $\left(\mathrm{LC}_{50}\right.$ of $\left.72 \mathrm{mg} / \mathrm{mL}\right)$ on A. salina and it was believed to be related with the high amount of tritepernes, particularly oleanolic acid, found in the plant (Montanher et al., 2002).

Plant species presenting high amount of flavonoids and alkaloids are reported as having interesting anti- $A$. salina property showing $\mathrm{LC}_{50}$ as low as of 0.13 $\mu \mathrm{g} / \mathrm{mL}$ (Pimenta et al., 2003; Cuadra et al., 2005). Still, sesquiterpenes, triterpenes, esterols, tanins e alkaloidscontaining Indian plants presented $\mathrm{LC}_{50}$ against $A$. salina ranging from 6.9 to $579 \mu \mathrm{g} / \mathrm{mL}$ (Padmaja et al., 2002).

Anti-malarial and anti-septic property was found in Lippia multiflora Moldenke (Verbenaceae), which also showed interesting citotoxicity toward A. salina $\left(\mathrm{LC}_{50}\right.$ of $1.1 \mu \mathrm{g} / \mathrm{mL}$ ) (Ajaiyeoba et al., 2006). Randomized clinical assays with $L$. multiflora essential oil showed anti-pediculosis activity, being reported that $\alpha$-pinene and $\beta$-pinene were the major compounds found in the oil (Oladimeji et al., 2000). Minquartia guianensis Aubl. (Olacaceae) extracts, which already showed an $\mathrm{LC}_{50}$ of $25.15 \mu \mathrm{g} / \mathrm{mL}$ on A. salina, are used in equatorial Amazon as antihelminthic (Marles \& Farnsworth, 1989).

Erler et al. (2006) studying the biological properties of essential oils from M. piperita L., Eucalyptus globulus L. (Mietaceae), Pimpinella anisum L. (Apiaceae) and Ocimum basilicum L. (Lamiaceae) noted repellent effect toward Culex pipens (filariosis etiological agent). The authors reported about the possibility of using their phytochemicals as alternative products to control vectorcausing diseases.

The findings of this study are in agreement with those previously noted by Luna et al. (2005) studying the biological properties of Ziziphus joazeiro Mart. (Rhamnaceae) and Caesalpinia pyramidalis Tul. (Fabaceae) where was found a correlation between the molluscicidal activity on A. salina and larvicidal activity toward A. aegypti.

The World Health Organization reports that plant extracts showing $\mathrm{LC}_{50}<40 \mathrm{ppm}(0.04 \% ; 0.4 \mu \mathrm{g} / \mathrm{mL})$ has some potential to be applied as molluscicidal or larvicidal compound (WHO, 1993). Facility to be prepared, water solubility and ability to impair the laying are some attributes to be regarded when analyzed a possible molluscicidal product (Clarck et al., 1997; Ruiz et al., 2005; Lhullier et al., 2006; Santos et al., 2007).

Regarding the interesting in vitro toxicity of the assayed essential oils on A. aegypti and the importance of the dengue in the public health, our results are promising, however it is necessary that complementary researches are performed focusing the possibility of their practical and rational application to impair the survival of the dengue etiological agent.

Our data reinforce the importance of plant products as source of new bioactive compounds and show the importance of preliminary bioassays as a screening of their biologic potentiality. Still regarding the results presented here, the assayed essential oils and phytochemicals could be inserted in further pre and clinical toxicological evaluation in order to establish a safe exploitation of their biological potentiality.

\section{REFERENCES}

Ajaiyeoba EO, Abiodun OO, Falade MO, Ogbole NO, Ashidi JS, Happi CT, Akinboye DO 2006. In vitro cytotoxicity studies of 20 plants used in Nigerian antimalarial ethnomedicine. Phytomedicine 13: 295-298.

Alves TMA, Silva AF, Brandão M, Grandi TSM, Smânia EFA, Smânia-Junior A, Zani CL 2000. Biological screening of brazilian medicinal plants. Mem Inst Oswaldo Cruz 96: 367-373.

Ara J, Sultana V, Ehteshamul-Haque S, Qasim R, Ahmad VU 1999. Cytotoxic activityof marine macro-algae on Artemia salina (brine shrimp). Phytother Res 13: 304307.

Clark TE, Appleton CC, Drewes SE 1997. A semi-quantitative approach to the selection of appropriate candidate plant molluscicides-A South African application. $J$ Ethnopharmacol 56: 1-13.

Conforti F, Statti G, Uzunov D, Menichini F 2006. Comparative chemical composition and antioxidant activities of wild and cultivated Laurus nobilis L. leaves and Foeniculum vulgare subsp. piperitum (Ucria) coutinho seeds. Biol Pharm Bull 29: 2056-2064.

Cuadra P, Furrianca M, Urrianca M, Oyarzún A, Yáñez E, Gallardo A, Fajardo V 2005. Biological activity of some Patagonian plants. Fitoterapia 76: 718-721.

Dip EC, Pereira NA, Fernandes PD 2004. Ability of eugenol to reduce tongue edema induced by Dieffenbachia picta Schott in mice. Toxicon 43: 729-735.

Erler F, Ulug I, Yalcinkaya B 2006. Repellent activity of five essential oils against Culex pipens. Fitoterapia 77: 491494.

FUNASA 2002. Dengue: aspectos epidemiológico, diagnóstico $e$ tratamento. http://www.defesacivil.sp.gov.br/ documentos/cartilha_dengue.pdf, acesso em 29 de julho 2007.

Lhullier C, Horta PA, Falkenberg M 2006. Avaliação de extratos de macroalgas bênticas do litoral catarinense utilizando o teste de letalidade para Artemia salina. Rev Bras 
Farmacogn 16: 158-163.

Lima NMF, Santos AF, Profirio Z, Goulart MOF, Sant'Ana AEG 2002. Toxicity of lapachol and isolapachol and their potassium salts against Biomphalaria glabrata, Schistosoma mansoni cercariae, Artemia salina and Tilapia nilotica. Acta Trop 83: 43-47.

Lopes WB, Moroni FT, Brandenburgo MIH, Hamaguchi A 2002. Desenvolvimento de um método alternativo ao uso de animais de laboratório para avaliação da toxicidade de extratos vegetais. http://www.propp.ufu. $\mathrm{br} /$ revistaeletronical/b/desenvolvimento.pdf, acesso em 16 de julho 2007.

Luna JS, Santos AF, Lima MRF, Omena MC, Mendonça FAC, Bieber LW, Sant'Ana AEG 2005. A study of the larvicidal and molluscicidal activities of some medicinal plants from northeast Brazil. J Ethnopharmacol 97: 199-206.

Marcondes CB 2001. Entomologia Médica e Veterinária. 1.ed. Belo Horizonte: Atheneu, p. 80-82.

Marles RJ, Farnsworth NR 1989. Isolation of a novel cytotocity polyacetylene from a traditional anthelmintic medicinal plant Minquartia guianensis. J Nat Prod 52: 261-266.

Martinez M, Del Ramo J, Torreblanca A, Díaz-Mayans J 1999. Effect of cadmium exposure on zinc levels in the brine shrimp Artemia partenogenetics. Aquaculture 172: 315325.

Matos FJA 1988. Introdução à Fitoquímica Experimental. 1.ed. Fortaleza: edições UFC. 1998. Farmácias Vivas: sistema de utilização de plantas medicinais. Projeto para pequenas comunidades. 3.ed. Fortaleza: Edições UFC, 220p.

McLaughlin JL, Rogers LL, Anderson JE 1998. The use of biological assays to evaluate botanicals. Drug Inf $J 32$ : 513-524.

Meyer BN, Ferrigni NR, Putnam JE, Jacobsen LB, Nichols DE, McLaughlin JL 1982. Brine Shrimp: a convenient general bioassay for active plant constituents. Planta Med 45: 31-34.

Montanher ABP, Pizolatti MG, Brighente IMC 2002. An application of the brine shrimp bioassay for general screening of brazilian medicinal plants. Acta Farm Bonaer 21: 175-178.

Oladimeji RA, Orafidiya OO, Ogunniyi TA, Adewunmi TA 2000. Pediculocidal and scabicidal properties of Lippia multiflora oil. J Ethnopharmacol 72: 305-311.

Oliveira MJR, Simões MJS, Sassi CRR 2006. Fitoterapia no Sistema de Saúde Pública (SUS) no estado de São Paulo, Brasil. Rev Bras Pl Med 8: 39-41.

Padmaja R, Arun PC, Prashanth D, Deepak M, Amit A, Anjana M 2002. Brine Shrimp lethality bioassay of selected Indian medicinal plants. Fitoterapia 73: 508-510.

Parra AL, Yhebra RS, Sardiñas IG, Buela LI 2001. Comparative study of the assay of Artemia salina L. and the stimulate of medium lethal dose ( $\mathrm{LD}_{50}$ value) in mice, to determine oral acute toxicity of plants extracts. Phytomedicine 8 : 395-400.

Pelka M, Danzl C, Distler W, Petschelt A 2000. A new screening test for toxicity testing of dental materials. $J$ Dent 28 : 341-345.

Pimenta LPS, Pinto GB, Takahashi JA, Silva LGF, Boaventura MAD 2003. Biological screening of Annonaceous Brazilian Medicinal Plants using Artemia salina (Brine Shrimp Test). Phytomedicine 10: 209-212.

Ruiz ALTG, Magalhães EG, Magalhães AF, Faria AD, Amaral MCE, Serrano DR, Zanotti-Magalhães EM, Magalhães LA 2005. Avaliação da atividade tóxica em Artemia salina e Biomphalaria glabrata de extratos de quatro espécies do gênero Eleocharis (Cyperaceae). Rev Bras Farmacogn 15: 98-102.

Sant'Ana LS, Mancini-Filho J 1999. Ação antioxidante de extratos de alecrim (Rosemary officinalis L.) em filés de peixe da espécie pacu (Piaractus mesopotamicus Holmberg). Rev Bras Pl Med 2: 27-31.

Santos AF, Azevedo DPL, Mata RCS, Mendonça DIMD, Sant'Ana AEG 2007. The lethality of Euphorbia conspicua to adults of Biomphalaria glabrata, cercaria of Schistosoma mansoni and larvea of Artemia salina. Bioresource Technol 98: 135-139.

Sellar W 2002. Óleos que curam-O poder da aromaterapia. Rio de Janeiro: Record, Nova Era.

Silva HHG, Silva IG, Lira KS 1998. Metodologia de criação, manutenção de adultos e estocagem de ovos de Aedes aegypti (Linnaeus, 1762) em laboratório. Rev Patol Trop 27: 51-63.

Simões CMO, Spitzer V 2003. Óleos voláteis. In: Simões CMO, Schenkel EP, Gosmann G, Mello JCP, Mentz LA, Petrovick PR. Farmacognosia: da planta ao medicamento. 5.ed. Porto Alegre/Florianópolis: Editora da UFRGS/Editora da UFSC, p. 467-495.

Souza EL, Stamford TLM, Lima EO, Trajano VN 2007. Efectiveness of Origanum vulgare L. essential oil to inhibit the growth of food spoiling yeasts. Food Control 18: 409-413.

Svensson BM, Mathiasson L, Martensson L, Bergstrom S 2005. Artemia salina as test organism for assessement of acute toxicity of Leachate water from Landfills. Environ Monit Assess 102: 309-321.

Tognolini M, Barocelli E, Ballabeni V, Bruni R, Bianchi A, Chiavarini M, Impicciatore M 2006. Comparative screening of plant essential oils: Phenylpropanoid moiety as basic core for antiplatelet activity. Life Sci 78: 14191432.

Vidal F, Vidal JC, Gadelha APR, Lopes CS, Coelho MGP, Monteiro-Leal LH 2007. Giardia lamblia: The effects of extracts and fractions from Mentha piperita Lin. (Lamiaceae) on trophozoites. Exp Parasitol 115: 25-31.

WHO 1993. Tropical Disease Research. Geneva: World Health Organization. 